\title{
Impact of spatial resolution on the hydrological simulation of the Durance high-Alpine catchment, France
}

\author{
Pierre Etchevers, ${ }^{1}$ Yves Durand, ${ }^{1}$ Florence Habets, ${ }^{2}$ Eria Martin, ${ }^{1}$ Joël Noilhan ${ }^{2}$ \\ ${ }^{1}$ Centre d'Études de la Neige/Centre National de Recherches Météorologiques/Météo-France, 1441 rue de la Piscine, \\ 38406 Saint-Martin-d'Hères Cedex, France \\ ${ }^{2}$ Centre National de Recherches Météorologiques/Météo-France, 42 Avenue Coriolis, 31057 Toulouse Cedex, France
}

\begin{abstract}
The water balance of the mountainous Durance river catchment, French Alps, is simulated from 1981 to 1994 with a soil-vegetation-atmosphere transfer (SVAT) model. Particular attention is paid to the snow-cover evolution using a detailed model of the snowpack evolution. The results are validated by comparison of the simulated discharges calculated by the SVAT with daily observations at three gauging stations located in the watershed. Three different spatial resolutions are used $(1,8$ and $46 \mathrm{~km})$ in order to evaluate the impact on the surface-water-budget results. Comparison with the finest resolution indicates the need for sub-grid-scale parameterization for the model with larger resolution.
\end{abstract}

\section{INTRODUCTION}

Much current meteorological research has the aim of improving the knowledge of vadose-zone processes. Indeed, several studies have shown that the soil water initialization in numerical atmospheric models is a major factor in the quality of short- and medium-range forecasting (Miyakoda and others, 1979; Yang and others, 1994; Beljaars and others, 1996). Calculation of the water and energy fluxes is commonly performed by soil-vegetation-atmosphere transfer (SVAT) models. SVAT models calculate the partitioning of precipitation into evaporation, surface runoff and drainage fluxes. This calculation is very complex because it depends strongly on the local surface characteristics (vegetation, soil properties), the actual soil water content and the atmospheric boundary layer. The physical laws used in the SVAT are generally locally calibrated, often by minimizing errors in the flux calculations. SVAT models are widely used in large-scale models, such as a global circulation model (GCM), and the locally calibrated laws are supposed to be valid at the GCM spatial scale (i.e. the size of the cells). However, some adaptations are required as a function of the spatial scale considered (Habets and others, 1999b). These improvements often consist in taking into account some subgrid-scale processes, which are not linear with respect to the spatial scale (like the precipitation distribution or the subgrid surface runoff over saturated soils). For a given resolution, the general question consists in determining the dominant physical processes to be included in the modelling. In this paper, this problem is treated in the particular case of a mountainous catchment. As the snowpack evolution is well known to be poorly captured by low-spatial-resolution models (Braun, 1991), the high Durance catchment in the Alps is studied using the same SVAT at three resolutions. Comparison of the simulated discharges with observations allows evaluation of the quality of results at different resolutions and identification of the main processes which control the snowpack evolution.

\section{THE DURANGE DATASET AND THE MODELS}

\subsection{The Durance high catchment}

The Durance high catchment is a relatively high-altitude catchment which lies in the southeast part of France, in the southern Alps. It contains small valleys upstream of the Serre-Ponçon dam (800 $\mathrm{m}$ a.s.l.), and its boundaries correspond to relatively high mountain ranges. The highest peak is the Massif des Ecrins (4102 m a.s.l.). The catchment average altitude is $2149 \mathrm{~m}$. Some glaciers exist at high altitudes, but they cover $<2 \%$ of the total surface area. The volcanic origin of the main mountains explains the lack of large water tables. There are only small water tables which have limited storage capacities and may contribute to the Durance discharge in summer. The small catchment storage capacity simplifies the modelling (no water-table simulation) and allows attention to be focused on surface processes. The watershed climate is dominated by the Mediterranean influence. The main precipitation occurs in autumn (generally as snow) and in spring (generally rainfall). The eastern part of the catchment (Queyras valley) is drier, except when the synoptic wind brings humidity from the east. The relatively low amount of liquid precipitation combined with the high average altitude explains the small extent of the forest $(26 \%$ of the catchment surface area). Half of the watershed is covered by grass, whereas the upper parts consist of rocks $(23 \%)$. The main watershed rivers are the Durance river itself and its main tributary, the Guil. There is only one small dam in the catchment, but its influence is not significant for the daily discharge (it can be seen on the observed discharge at Briançon-aval (Fig. 3, shown later), where small peaks occur at the end of each week due to local electricity production).

\subsection{Models}

\subsubsection{ISBA}

Because of the relatively small underground domain (small isolated water tables), the modelling is limited to the first few 
meters of the soil surface. The interaction soil-biosphereatmosphere (ISBA) scheme is used in the global circulation model (GCM) and numerical weather prediction (NWP) model of the FrenchWeather Service (Météo-France) (Noilhan and Planton, 1989; Giard and Bazile, 2000) and has participated in all the phases of the project for intercomparison of land-surface parameterization schemes (PILPS) (HendersonSellers and others, 1993). A revised description of ISBA can be found in Noilhan and Mahfouf (1996). ISBA has six prognostic variables: the soil water contents of the surface, root zone and deep soil and of the interception reservoir, and the surface and deep-soil temperatures. This three-layer version of ISBA (Boone and others, 1999) is based on a generalized force-restore method, and has been calibrated using a detailed soil water transfer model. The deeper layer can feed the root-zone layer through capillary rises, and only the water of the root zone is directly available for transpiration. Two parameterizations are particularly well adapted for hydrological purposes. First, the sub-grid surface runoff allows the fraction of the cell where the soil surface is saturated to be taken into account. Secondly, the drainage parameterization was slightly improved by adding a minimum base flow in dry soil conditions, which permits the model to simulate very low discharge, for instance in summer. The parameters for parameterizations are assumed uniform for the whole watershed, as prescribed by Habets and others (1999b). In order to validate the surface-water and energybudget calculations, the discharge is simulated with ISBA. The drainage and the surface runoff are calculated every $5 \mathrm{~min}$ and are accumulated daily. Every day, the sum of these two amounts is considered to flow directly into the river. Since the maximum water-transfer time is approximately 1 day, one can consider that this discharge estimation is relevant at the daily scale.

\subsubsection{Crocus}

The simulation of the snowpack plays a major role for modelling mountainous catchments such as the Durance. Therefore, we used Crocus, a detailed snow model initially developed at Météo-France for avalanche-hazard forecasting. Crocus is a one-dimensional snow model which simulates the evolution of the snowpack characteristics as a function of weather conditions (Brun and others, 1989, 1992). The model results have been compared with observations at various scales: locally in the PILPS 2d intercomparison phase (Schlosser and others, 2000) and at Col de Porte (Brun and others, 1992), regionally in the French Alps (Martin and others, 1994) and for the entire Northern Hemisphere (Brun and others, 1997; Etchevers and others, 1999). Since Crocus is a physically based model, one of its main strengths is the capacity to simulate the snowpack for a large range of climatic conditions. Consequently, Crocus needs a complete set of meteorological parameters (including cloudiness and incoming radiation), which are not always available. The model estimates the internal state of the snowpack: temperature, liquid-water content, density and snow types. For calculating the different variables, the snowpack is divided into layers $(1-50)$ which are parallel to the surface slope. The following phenomena are taken into account by the model: the energy exchanges inside the snowpack and at the snowsoil and snow-atmosphere interfaces; the absorption of solar radiation with depth; the phase changes between solid and liquid water; the water transmission through the snowpack; the mass exchanges due to precipitation and water runoff; the compaction and the metamorphism of the snow.

\subsubsection{Coupling ISBA and Crocus}

The time-step of Crocus (15 min) is larger than that of ISBA ( $5 \mathrm{~min})$. Crocus derives the evolution of the snow water equivalent (SWE) as a function of the meteorological parameters by calculating the amounts of sublimation/condensation and melting. The conduction flux at the snow-soil interface depends on the temperature gradient between the snow bottom and the soil surface. Water from snowmelting is transferred to ISBA and added to the rain which falls on the snow-free part of the gridcell. There is no direct interaction between snow and vegetation, although forests can significantly modify the surface parameters at the snow surface (e.g. the air temperature or the incoming radiation).

\subsection{Data}

\subsubsection{Vegetation and soil data}

All the ISBA parameters are determined from the soil-texture and vegetation maps (Noilhan and Lacarrère, 1995), except for the parameters for the sub-grid surface runoff and drainage schemes. The soil and vegetation maps have been determined using the soil database from the Institut National de Recherches Agronomiques (King and others, 1995), a 2 year satellite archive of the Advanced Very High Resolution Radio meter/normalized-difference vegetation index (AVHRR/ NDVI) (Champeaux and Legléau, 1995) and some information from the Corine Land Cover database (Giordano, 1990). The main soil characteristics used to derive the soil properties are the sand- and clay-composition fractions. The vegetation is described by the vegetation fraction, the leaf-area index (LAI) and the minimum stomatal resistance. The soil and vegetation data resolution is generally $1 \mathrm{~km}$, so the data were aggregated at coarser resolution (8 and $46 \mathrm{~km}$ ) following the Noilhan and Lacarrère (1995) method. The calibrations of the ISBA parameters based on the vegetation characteristics were established in the Adour watershed, southwest France, in a previous study (Habets and others, 1999a) and are kept identical for the Durance case. For each vegetation type, a monthly evolution of the vegetation parameters between prescribed maximum and minimum values is based on the monthly values of NDVI. Therefore, for each vegetation type, only the extreme values of the vegetation parameters have to be imposed.

\subsubsection{Meteorological data}

Because of the high altitude of the watershed, it is important to take into account the impact of orography on the assimilation of the atmospheric forcing. The Système d'Analyse Fournissant des Renseignements Atmosphériques à la Neige (SAFRAN) analysis (Durand and others, 1993), which was developed for avalanche-hazard forecasting, produces the assimilation of low-level atmospheric quantities needed by the surface scheme at an hourly time-step: cloudiness, liquid and solid precipitation, incoming radiation fluxes, mean wind speed, air temperature and humidity at screen level. The SAFRAN analysis is especially well adapted to the interpolation of the atmospheric forcing in mountainous areas, and has been extended to the Durance watershed (Etchevers, 2000). The three kinds of data used in SAFRAN are: screen-level observations, European Centre for Mediumrange Weather Forecasts analysis and climatological data. Incoming radiation fluxes are computed from the radiative 
transfer scheme of Ritter and Geleyn (1992). In the Durance watershed, the weather measurements consist of one synoptic $6 \mathrm{~h}$ observation of the main surface meteorological parameters (Embrun) and 16 daily observations of the precipitation from the French climatological network.

\subsubsection{Validation data}

The validation data consist of daily discharge observations from 1981 to 1994 at three gauging stations located on the Durance river: Briançon-aval (sub-catchment surface area: $\left.548 \mathrm{~km}^{2}\right)$, l'Argentière $\left(984 \mathrm{~km}^{2}\right)$ and la Clapière, at the outlet of the watershed $\left(2170 \mathrm{~km}^{2}\right)$ (Fig. 1).

\subsection{Modelling experiments}

As indicated previously, no particular calibration was done for the catchment. The ISBA calibrations were carried out during specific measurement campaigns and improved in the Adour study (Habets and others, 1999a) and are kept unchanged. The Adour basin is very different from the Durance catchment: it is mainly covered by crops and forests and lies close to sea level. The Adour basin has no mountainous part, and snow is very rare. In spite of these differences, some calibrations done for the Adour basin are successfully used for the Durance catchment simulation (e.g. the sub-grid runoff scheme). The initial state of the model is obtained after a spin-up simulation on the first year. Thus, 1981/82 was simulated twice by using the final state of the model to initialize it again. The spin-up method permits an equilibrium state to be reached that is coherent with the soil characteristics (temperature and humidity). The simulation begins on 1 August 1981 and ends on 31 July 1994, without intermediate re-initialization. The fact that the simulation begins in August permits a reduction of the error due to the missing data for the initial state of the snowpack.

Three experiments are presented, using the same modelling framework and input data, but with an increasing spatial resolution. The experiment $\mathrm{R} 1 \mathrm{~km}$ ( $1 \mathrm{~km}$ resolution) uses 2170 cells of $1 \mathrm{~km}^{2}$ surface area, whereas the intermediate experiment R8km (8 km resolution) uses 50 cells (Fig. 1). The third experiment $\mathrm{R} 46 \mathrm{~km}$ consists in only one calculation for the whole catchment and is equivalent to a $46 \mathrm{~km}$ resolution. The soil and vegetation data are available at a resolution of $1 \mathrm{~km}$. For R8km and $\mathrm{R} 46 \mathrm{~km}$, these data are aggregated, following the method proposed by Noilhan and Lacarrère (1995). The meteorological parameters are issued from the same SAFRAN analysis and are interpolated at the gridcell altitude.

\section{RESULTS}

\subsection{Main characteristics of water-budget components}

The annual amount of precipitation is moderate (about $1000 \mathrm{~kg} \mathrm{~m}^{-2} \mathrm{a}^{-1}$ ), and more than half falls in the form of snow. The total precipitation spatial distribution ranges from $800 \mathrm{~kg} \mathrm{~m}^{-2} \mathrm{a}^{-1}$ in the valleys to about $1600 \mathrm{~kg} \mathrm{~m}^{-2} \mathrm{a}^{-1}$ in the highest parts of the catchment. The actual evapotranspiration (AET) ranges from $600 \mathrm{~kg} \mathrm{~m}^{-2} \mathrm{a}^{-1}$ in the lowest parts (close to la Clapière) to $100 \mathrm{~kg} \mathrm{~m}^{-2} \mathrm{a}^{-1}$ in the Massif des Ecrins, where evaporation is strongly limited by the lack of vegetation and the presence of a persistent snowpack. Thus, the ratio between AET and total precipitation reaches $60 \%$ in the valleys and remains below $20 \%$ in the highest mountains. In contrast, the total runoff reaches its highest values in the mountainous part (Runoff/Total pre-

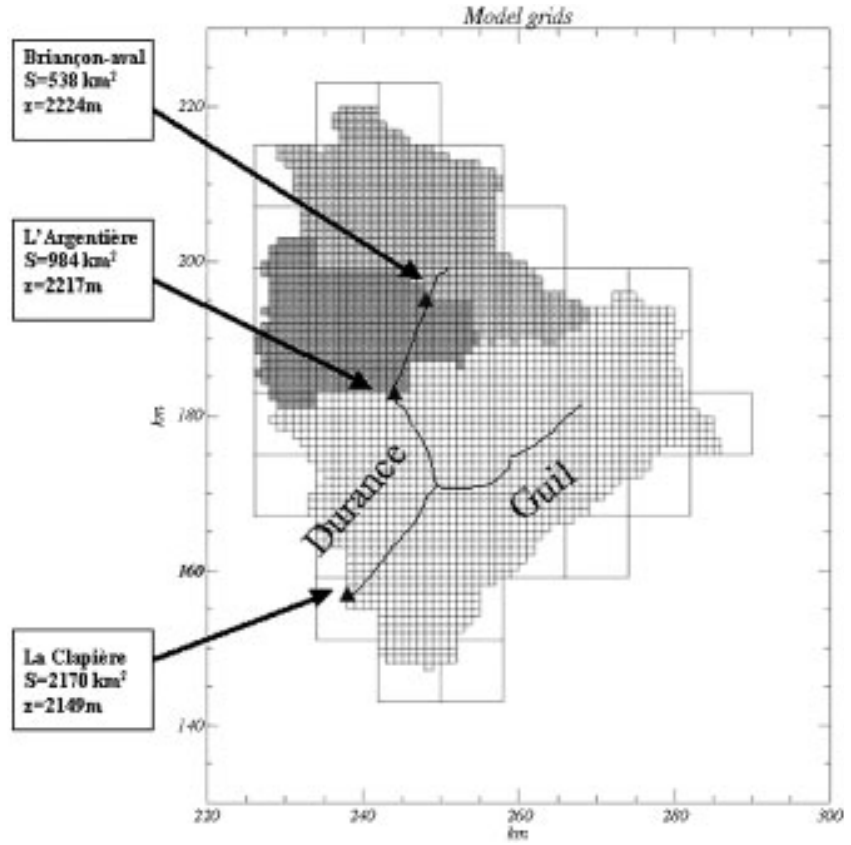

Fig. 1. Map of the catchment. Each gauging station is plotted with a triangle, and the corresponding sub-catchment is drawn with a different shade (the surface area $S$ and the mean altitude are given). The two grids correspond to the experiments $R 1 \mathrm{~km}$ (resolution $1 \mathrm{~km}, 2170$ cells) and R8km (resolution $8 \mathrm{~km}, 50$ cells).

cipitation $>80 \%$ ), and most of the precipitation flows to the rivers (by runoff or drainage following rainfalls or snowmelt). The snowpack features are also very dependent on the topography. The mean snow depth (during the snow season) reaches $120 \mathrm{~cm}$ on the Massif des Ecrins and is $>50 \mathrm{~cm}$ in the largest part of the basin. The annual maximum snow depth (averaged for 14 years) is $>2 \mathrm{~m}$ on the main mountains ( $>2500 \mathrm{~m}$ a.s.l.) and is $>1 \mathrm{~m}$ for the whole catchment (except for a small low-altitude fraction). The annual snow-cover duration is 120 days on average on the Durance watershed, but is $>150$ days in the highest parts. In some cells corresponding to the Massif des Ecrins glacierized areas, the snow accumulates continuously, without disappearing during summer. Therefore, even if the glaciers are not explicitly taken into account in the simulation, the modeled snowpack tends to have a similar behaviour, with a very close impact on the hydrological response and the surface energy and water exchanges. If one neglects the soil water-storage variations between the beginning and the end of the 14 year simulation, the annual amount of precipitation $\left(1064 \mathrm{~kg} \mathrm{~m}^{-2} \mathrm{a}^{-1}\right.$ on average, 1981-94) divides into one-third AET (348 $\left.\mathrm{kg} \mathrm{m}^{-2} \mathrm{a}^{-1}\right)$ and two-thirds runoff $\left(713 \mathrm{~kg} \mathrm{~m}^{-2} \mathrm{a}^{-1}\right)$ for the whole catchment. As shown in Table 1 , the mean annual amounts of AETand total runoff do not significantly differ for the three experiments. The relative difference of the AET $(2-4 \%)$ and of the total runoff $(1-4 \%)$ between the three experiments is in the same order as the relative difference of the precipitation amount (due to the meteorological interpolation with different spatial resolution). The monthly partition of AET and runoff also differs slightly in the three experiments. Thus, the annual and monthly water budgets do not depend significantly on the spatial resolution for the considered spatial scale $\left(500-2000 \mathrm{~km}^{2}\right)$.

\subsection{Impact of the resolution on the calculations}

The main impact of the adopted resolution is noticeable for 
Table 1. Values of the surface water budget components of the whole catchment (precipitation, evaporation and runoff, all in $\mathrm{mm}^{-1}$ ) compared with the Nash criterion and the ratio between simulated and observed discharges at la Clapière

\begin{tabular}{ccccrc}
\hline Resolution & Precipitation Evaporation & Runoff & $\begin{array}{c}\text { Nash } \\
\text { criterion }\end{array}$ & Qsim/Qobs \\
\hline $1 \mathrm{~km}$ & 1064 & 348 & 713 & 0.80 & 0.96 \\
$8 \mathrm{~km}$ & 1061 & 344 & 713 & 0.72 & 0.94 \\
$46 \mathrm{~km}$ & 1084 & 345 & 748 & -1.85 & 1.00 \\
\hline
\end{tabular}

Note: The annual water amounts and the statistical criteria are averaged from 1981 to 1994

the snowpack evolution. With a single calculation (experiment R46km), the snowpack appears in October and disappears at the beginning of June, with a maximum SWE of $390 \mathrm{~kg} \mathrm{~m}^{-2}$ (on average for the whole catchment) at the end of March (Fig. 2a). With the resolution of $8 \mathrm{~km}$, the annual cycle of the snowpack differs slightly and the maximum occurs at the same date. But the increase and decrease of the snowpack are smoother. The snow never completely disappears (some snow persists in the Massif des Ecrins) and the maximum accumulation is smaller $\left(360 \mathrm{~kg} \mathrm{~m}^{-2}\right)$. For the finest resolution $(1 \mathrm{~km})$, the transition from summer to winter is smoother than in $\mathrm{R} 8 \mathrm{~km}$, and the maximum accumulation is lower $\left(335 \mathrm{~kg} \mathrm{~m}^{-2}\right)$. During summer, the fraction of persistent snow is slightly larger. The different snowpack features in the three experiments are explained by the better resolution of the topography. In Rlkm, the snowpack can more easily persist during summer because of the high altitude of the upper gridcells. In contrast, the winter accumulation is weaker, due to the faster melt in the lower cells of the domain (800-1000 m a.s.l.). The snow-covered surface

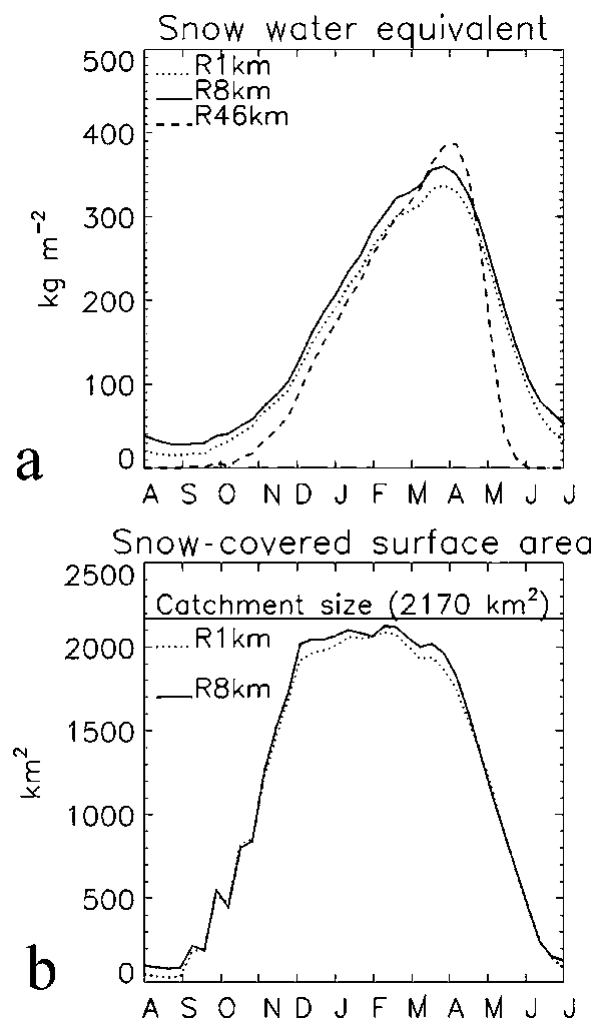

Fig. 2. Snow water equivalent averaged for the whole catchment (a) and snow-covered surface area (b) for R1km (dotted line), Rokm (solid line) and R46km (dashed line). area increases at the same rate for $\mathrm{R} 1 \mathrm{~km}$ and $\mathrm{R} 8 \mathrm{~km}$, but the maximum is weaker for the $1 \mathrm{~km}$ than for the $8 \mathrm{~km}$ resolution (Fig. 2b). The Rlkm snow-free area allows slightly more evaporation during the winter season.

The main impact of the snow evolution is noticeable on the river discharge during the snowmelt. The Durance regime is typically a mountainous river regime. During autumn, the discharge is generally low, except when strong rainfall occurs. In winter, the main part of the watershed is snow-covered and the climatic conditions do not allow snowmelt, so the discharges are very low. The main peaks occur during spring when the snow melts; they can reach $50 \mathrm{~m}^{3} \mathrm{~s}^{-1}$ at Briançon-aval and $150 \mathrm{~m}^{3} \mathrm{~s}^{-1}$ at la Clapière. The discharge then decreases under summer climatic conditions (low precipitation, high air temperatures) and stays very low until autumn, except when a severe storm affects the watershed.

The comparison of the simulated discharge for Rlkm and R8km with the daily observations of the three gauging stations is illustrated in Figure 3 for the year 1985/86, which is representative of the impact of changing the resolution. At Briançon-aval, the maximum value of the observed discharge is $80 \mathrm{~m}^{3} \mathrm{~s}^{-1}$ (at the end of May), whereas the maximum value of simulated discharge is $172 \mathrm{~m}^{3} \mathrm{~s}^{-1}$ in $\mathrm{R} 8 \mathrm{~km}$ and $118 \mathrm{~m}^{3} \mathrm{~s}^{-1}$ in $\mathrm{R} 1 \mathrm{~km}$. The second melting flash flood (in mid-June) is also better simulated with a $1 \mathrm{~km}$ resolution. In particular, the peak is smoother and the discharge then diminishes more slowly than in $\mathrm{R} 8 \mathrm{~km}$, which is more in accordance with the observations. The same improvements are noticeable for l'Argentière and la Clapière gauging stations: the relative error on the maximum discharge is reduced from $76 \%$ to $30 \%$ at l'Argentière and from $46 \%$ to $19 \%$ at la Clapière. In the same way, the phases of increase and decrease of the melting-period peak are better captured at the $1 \mathrm{~km}$ resolution.
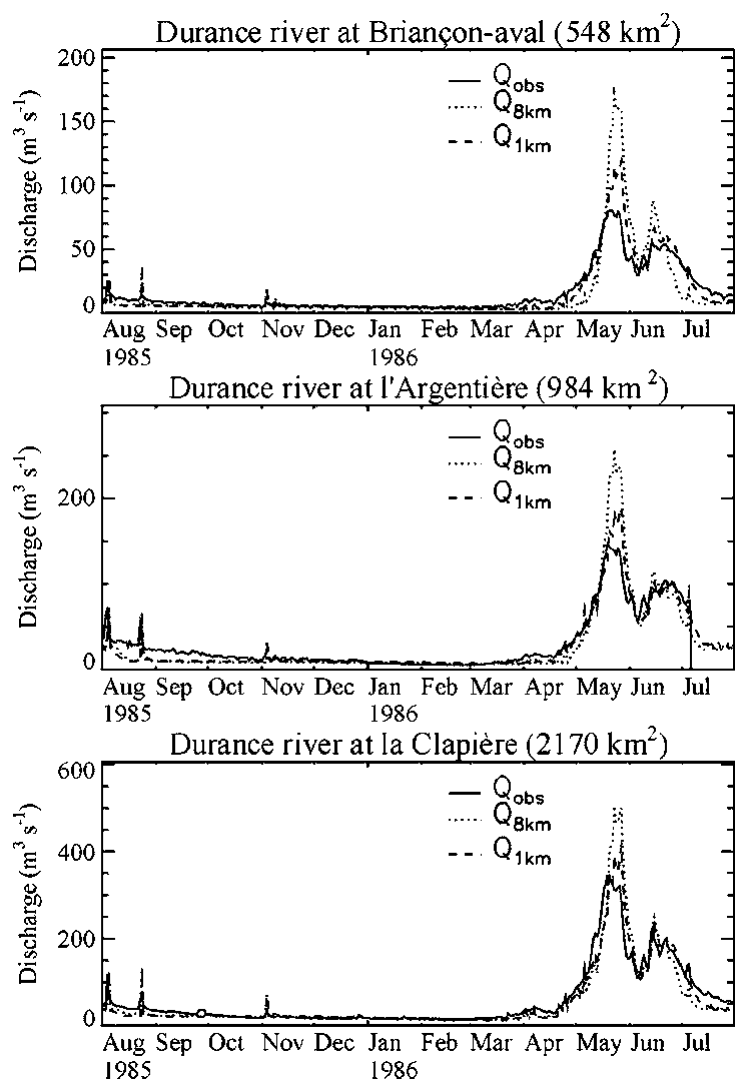

Fig. 3. Daily discharges observed at the three gauging stations ( solid line) and simulated in the experiments Rokm (dotted line) and R1km (dashed line), 1985/86. 

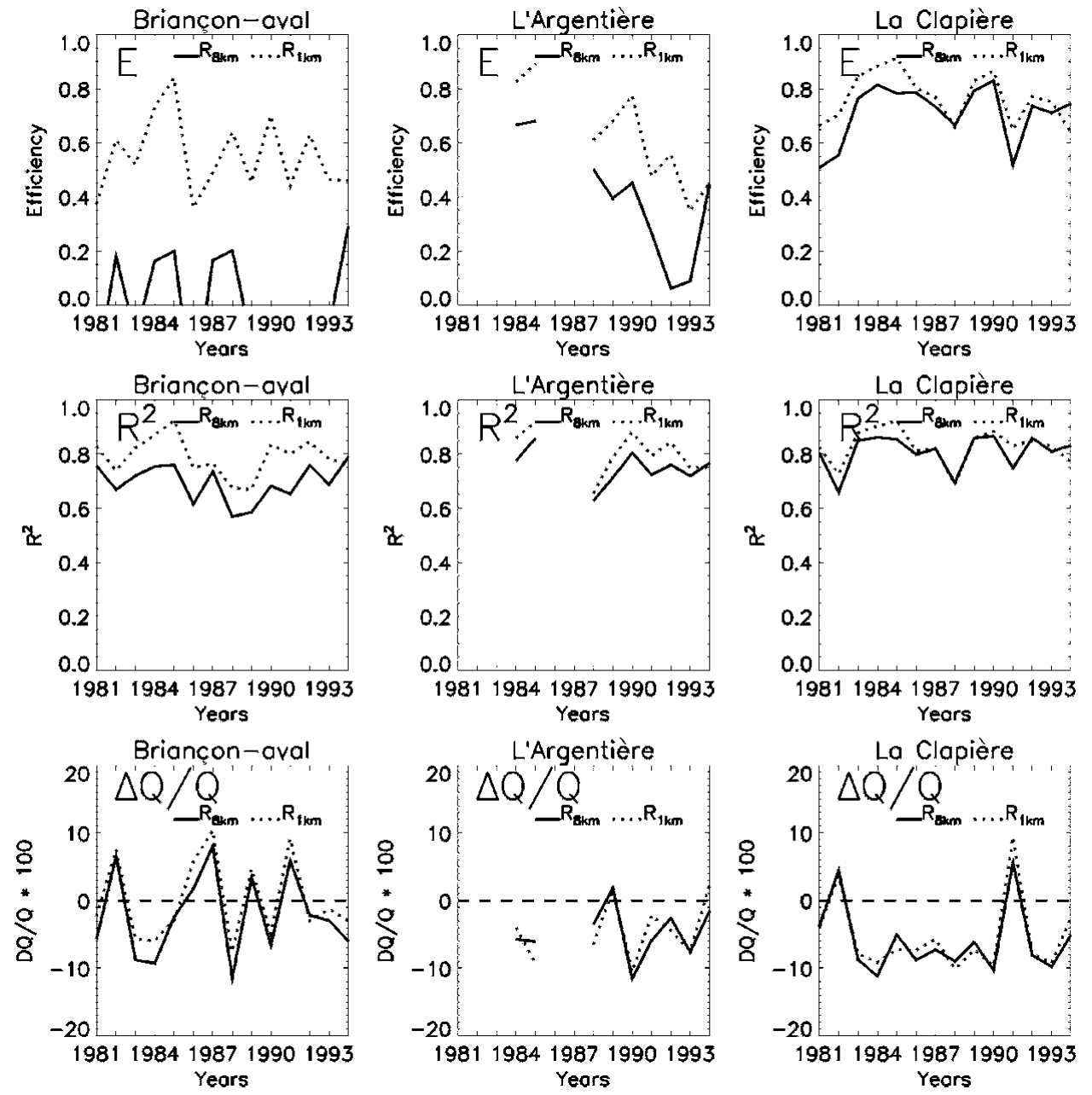

Fig. 4. Annual statistical parameters, 1981-94: Nash criterion E (upper graphs), correlation criterion R2 (middle graphs) and relative error on the annual discharges $\Delta Q / Q$ (lower graphs). For each gauging station, the solid line corresponds to Rokm, and the dotted line to R1km.

Even at the finest resolution, the maximum amplitude of the melting-period peaks is overestimated by the model, whereas the simulated-discharge increasing and decreasing phases are not so smooth as the observed ones. This could be due to the lack of small-aquifers simulation (which could smooth the water transfer to the river) or to the simplified snowpack simulation (no interaction between snow and forests, no snow redistribution by wind).

The annual statistical parameters confirm the marked improvement of the discharge simulation. At Briançon-aval, the relatively poor $\mathrm{R} 8 \mathrm{~km}$ Nash criterion (generally negative) is improved to values of $0.5-0.7$ at $1 \mathrm{~km}$ resolution (Fig. 4). At la Clapière, the Nash criterion increases from 0 to 0.2 , varying from $0.6-0.7$ values to $0.75-0.85$ values. In contrast, no significant improvement appears for the annual mean discharge. At Briançon-aval, the great overestimation of $1987 / 88(+8 \%)$ and the good estimation of 1989/90 (+3\%) are simulated in the same proportion in both experiments. On average for the 14 years, the Nash criterion at la Clapière ranges from $-1.85(\mathrm{R} 46 \mathrm{~km})$ to $0.72(\mathrm{R} 8 \mathrm{~km})$ and $0.8(\mathrm{R} 1 \mathrm{~km})$, whereas the annual discharge error is very close to 1 for the three experiments (Table 1).

\section{DISCUSSION}

The Durance high-altitude watershed is simulated with three spatial resolutions: 1,8 and $46 \mathrm{~km}$. The results show that the monthly and annual components of the water budget (AET, total runoff) do not depend on the resolution and are similar for the three experiments. The monthly discharges are used to validate the calculations and are similar to the observations. For the annual and monthly scale, the SVAT seems valid when used at the catchment scale. The validation scale ranges from a very fine scale close to the calibration scale $(1 \mathrm{~km})$ to the GCM-resolution typical scale $(46 \mathrm{~km})$.

The main differences appear when one considers the daily values of the observed discharges. The simulated discharge improves as the resolution is increased. The most improved aspect is the melting-period peak, since the error of the maximum peak is reduced by $20 \%$ at la Clapière and $50 \%$ at Briançon-aval. This improvement is explained by the better resolution of the watershed topography, which allows a smoother and more realistic snowpack evolution. Thus, the evolution of the $\mathrm{R} 46 \mathrm{~km}$ snowpack is representative of a mean altitude snowpack, but does not give a good image of the entire catchment snowpack evolution. The $\mathrm{R} 8 \mathrm{~km}$ simulation is an intermediate estimation, closer to reality than $\mathrm{R} 46 \mathrm{~km}$, but with too coarse a resolution for the topography. The $1 \mathrm{~km}$ resolution experiment permits simulation of the summer high altitude and the winter snow-free areas located near the outlet. The main improvement is due to the better distribution of the catchment altitudes, which allows the model to take into account the non-linear evolution and distribution of the snowpack with elevation. A simple improvement of the R8km simulation 
will consist of taking into account the sub-grid variability of the altitude inside the gridcell. Such a sub-grid parameterization will allow the use of a coarse resolution (i.e. $8 \mathrm{~km}$ ) with comparable discharge simulation quality in comparison with the $1 \mathrm{~km}$ resolution. The error in the maximum value of the discharge peak should be reduced in the same proportion (about half of the relative error).

For the finest resolution $(1 \mathrm{~km})$, the next model improvements will be related to the shape of the melting-period peaks. This will necessitate more accurate modeling of some physical processes. For instance, the interactions between snow and forests are probably significant during the melting period, since forests can retain snow longer than grassland. The snowpack evolution in the forest can also be quite different during winter, because of the radiation perturbation, the snow interception and the wind reduction by trees (Durot, 1999). As mentioned before, we do not explicitly model the glaciers, which can have an important role in snow accumulation and snow retention until mid-summer. The snow distribution by wind can also modify the snow cover of the watershed and smooth the melting-peak shape (Braun and others, 1994). Lastly, the soil model is limited to an unsaturated zone (up to $3 \mathrm{~m}$ ) and completely ignores the underground lateral and vertical water transfers and storage. In particular, some isolated small water tables retain water for long periods and deliver this water during the following months, sustaining the low winter or summer discharges. This aspect could be improved by using a hydrological model adapted to the mountainous watersheds.

\section{CONGLUSION}

This application of the model shows its ability to simulate the Durance river mountainous regime. The snowmelt peaks are generally reproduced at the right time, even if their maximum amplitude is often overestimated. The three experiments with different resolution permit one to conclude that the annual and monthly calculated values of the water budget are independent of the spatial resolution. This reinforces one of the main assumptions of the SVAT models, namely, that the locally calibrated laws are valid for larger resolutions $(1-46 \mathrm{~km})$. This conclusion applies to the Durance watershed, but a very similar conclusion was obtained for the Rhône basin by comparing the simulations at 8 and $100 \mathrm{~km}$ resolutions (Habets and others, 1999b). The main error to be corrected is the overestimation of the maximum spring daily discharges. Since the simulated monthly discharges are generally good, the improvement of the discharge simulation should consist in a smoother decrease and increase of the melting period peaks. Our efforts will now be directed at improving the physical-processes simulation by including some sub-grid parameterizations such as snow/forest interactions and the effects of the sub-grid variability of the topography.

\section{AGKNOWLEDGEMENTS}

The authors wish to thank J.-L. Champeaux for providing vegetation data, C. Obled for frequent advice, and U. Strasser and $\mathrm{A}$. Boone for their assistance with preparing the final form of this paper.

\section{REFERENCES}

Beljaars, A. C. M., P.Viterbo, M. J. Miller and A. K. Betts. 1996. The anomalous rainfall over the USA during July 1993: sensitivity to land surface parameterization and soil moisture anomalies. Mon. Weather Rev., 124(3), 362-383.

Boone, A., J. C. Calvet and J. Noilhan. 1999. Inclusion of a third soil layer in a land-surface scheme using the force-restore method. f. Atmos. Sci., 38(11), 1611-1630.

Braun, L. N. 1991. Modelling of the snow-water equivalent in the mountain environment. International Association of Hydrological Sciences Publication 205 (Symposium at Vienna 1991 - Snow, Hydrology and Forests in High Alpine Areas), 3-17.

Braun, L. N., E. Brun, Y. Durand, E. Martin and P. Tourasse. 1994. Simulation of discharge using different methods of meteorological data distribution, basin discretization and snow modelling. Nord. Hydrol., 25(1-2), 129-144.

Brun, E., E. Martin, V. Simon, C. Gendre and C. Coléou. 1989. An energy and mass model of snow cover suitable for operational avalanche forecasting. $\mathcal{F}$. Glaciol., 35(121), 333-342.

Brun, E., P. David, M. Sudul and G. Brunot. 1992. A numerical model to simulate snow-cover stratigraphy for operational avalanche forecasting. f. Glaciol., 38(128), 13-22.

Brun, E., E. Martin and V. Spiridonov. 1997. Coupling a multi-layered snow model with a GCM. Ann. Glaciol., 25, 66-72.

Champeaux, J. L. and H. Legléau. 1995. Vegetation mapping over Europe using NOAA/AVHRR. In The 1995 Meteorological Satellite Data Users Conference, Winchester, U.K. Proceedings. Winchester, EUMETSA, 139-143.

Durand, Y., E. Brun, L. Mérindol, G. Guyomarc'h, B. Lesaffre and E. Martin. 1993. A meteorological estimation of relevant parameters for snow models. Ann. Glaciol., 18, 65-71.

Durot, K. 1999. Modélisation hydrologique distribuée du bassin versant nivopluvial de Sarennes. Validation de données d'entrée et développement d'un module de fonte nivale sous forêt. (Ph.D. thesis, Institut National Polytechnique de Grenoble.

Etchevers, P. 2000. Modélisation de la phase du cycle continentale de l'eau à l'échelle régionale: impact de la modélisation de l'enneigement sur l'hydrologie du bassin versant du Rhône. (Ph.D. thesis, Université Paul Sabatier, Toulouse.)

Etchevers, P., H. Douville and E. Martin. 1999. Simulation of the Northern Hemisphere snow cover. International Association of Hydrological Sciences Publication 256 (Symposium at Birmingham 1999 - Interactions between the Cryosphere, Climate and Greenhouse Gases), 3-10.

Giard, D. and E. Bazile. 2000. Implementation of a new assimilation scheme for soil and surface variables in a global NWP model. Mon. Weather Rev., 128(4), 997-1015.

Giordano, A. 1990. CORINE soil erosion risk and important land resources. Luxembourg, Office of Official Publications of the European Communities. (Technical Report EUR 12233 EN.)

Habets, F. and 9 others. 1999a. Implementation of the ISBA surface scheme in a distributed hydrological model, applied to the Hapex-Mobilhy area (I and II). 7. Hydrol., 217 (1-2), 75-118.

Habets, F. and 7 others. 1999b. Simulation of the water budget and the river flows of the Rhône basin. F. Geophys. Res., 104(D24), 31,145-31,172.

Henderson-Sellers, A., A.-L. Yang and R. E. Dickinson. 1993. The project for intercomparison of land-surface parameterization schemes. Bull. Am. Meteorol. Soc., 74(7), 1335-1349.

King, D., C. Lebas, M. Jamagne, R. Hardy and J. Draoussin. 1995. Base de données géographiques des sols de France à l'échelle 1/1,000,000. Avignon, Institut National de Recherches Agronomiques (INRA). (Technical Report.)

Martin, E., E. Brun and Y. Durand. 1994. Sensitivity of the French Alps snow cover to the variation of climatic variables. Annales Geophysicae, Atmospheres, Hydrospheres and Space Sciences, 12 (5), 469-477.

Miyakoda, K., J. Sirutis and R.F. Strickler. 1979. Cumulated results of extended forecast experiment. Part II: Model performance for summer cases. Mon. Weather Rev., 107(4), 395-420.

Noilhan, J. and P. Lacarrère. 1995. GCM gridscale evaporation from mesoscale modelling. 7. Climate, $\mathbf{8}(2), 206-223$.

Noilhan, J. and J.-F. Mahfouf. 1996. The ISBA land-surface parameterization scheme. Global and Planetary Change, 13, 145-159.

Noilhan, J. and S. Planton. 1989. A simple parameterization of land surface processes for meteorological models. Mon. Weather Rev., 117(3), 536-549.

Ritter, B. and J.-F. Geleyn. 1992. A comprehensive radiation scheme for numerical weather prediction models with potential applications in climate simulations. Mon. Weather Rev., 120(2), 303-325.

Schlosser, C. A. and 33 others. 2000. Simulations of a boreal grassland hydrology at Valdai, Russia: PILPS 2(d). Mon. Weather Rev., 128(2), 301-321.

Yang, R., M. J. Fennessy and J. Shukla. 1994. The influence of initial soil wetness on medium-range surface weather forecasts. Mon. Weather Rev., $122(3), 471-485$. 